\title{
Comparison of the Catching-up Path of Latecomer Firms: An Empirical Analysis Based on the Perspective of Technological Catching-up
}

\author{
Tong $\mathrm{Ye}^{*}$ \\ International Business School \\ Tianjin University of Finance and Economics \\ Tianjin, China \\ iptongmail@163.com
}

\author{
Linpei Zhang \\ School of Statistics \\ Tianjin University of Finance and Economics \\ Tianjin, China
}

\author{
Wenting Huang \\ International Business School \\ Tianjin University of Finance and Economics \\ Tianjin, China
}

\begin{abstract}
The aim of this study was to provide guidance for latecomers to make the choice of catching-up paths under the unique technological situation in China. This study clarifies the specific situation of the effectiveness of catching-up paths and investigates how the three catching-up paths affect the latecomers' catching-up performance. The present study was designed to establish a theoretical framework based on Lee and Lim's theory and put forward two hypotheses. These hypotheses were tested by large-sample empirical analysis including constructing structural and measurement models. The results suggest that among three technological catching-up paths, the influence of the path-creating catching-up is the most significant. Technological catching-up paths, which have a strong impact on market share and patent number, determine the catching-up performance. These results obtain general rules and break through the limitations of several specific industries providing a more macroscopic understanding of the effect of catching-up path choices on catching-up performance at the enterprise level.
\end{abstract}

Keywords - technological catching-up; latecomer firms; path selection; empirical analysis

\section{INTRODUCTION}

In recent years, China's economy has developed very rapidly. However, under the current severe international situation, China's latecomer firms have the disadvantages of limited catching-up time and insufficient technological innovation. At the same time, enterprises are also facing the problems of high cost caused by independent technological innovation. Therefore, it is particularly important to study how the latecomer firms can integrate the existing resources of the market and the internal resources of the enterprise more effectively to select the appropriate catching-up path, thereby improving the catching-up performance and market competitiveness of the enterprise. Zang Shuwei [1] believes that with the advent of the Internet era, compared with technological innovation, business model innovation is more conducive to latecomer firms to gain competitive advantage and improve catching-up performance. However, this paper believes that as a latecomer firm, if it only relies on the innovation of business model and does not have strong technical innovation support, it is difficult for it to increase its market share and achieve catching-up. Wu Dong [2], Lin Runhui [3], Liu [4] et al. believe that technological innovation is an important way for latecomer firms to achieve technological catching-up. Chen Zhu [5] and others divide the technological innovation of latecomer firms into two aspects: independent research and development and first introduction and transformation. They believe that these two aspects should maintain a dynamic balance and avoid a stalemate that is only imitative and not innovative. In contrast, Wu Xiaobo [6] and others believe that the technological innovation of latecomer firms should adopt a secondary innovation approach. By introducing similar products of the same industry, a firm can digest and absorb the respective advantages and technologies of the products, and then innovate a unique technology or product. Therefore, in view of the above problems and existing researches, this paper combines two aspects of enterprise technology innovation and proposes three technological catching-up paths under the perspective of technology catching-up. Through a large sample empirical analysis of 259 latecomer firms that have successfully pursued catching-up, this paper analyzes the catching-up paths adopted by these firms and proposes a general-purpose conclusion which may help the current latecomer firms in the "followers" stage to choose the suitable path to catch up and improve the catching-up performance in the process of becoming a "leader" more effectively. Specific research issues include: (1) From a technical perspective, how do the catching-up paths of latecomer firms affect the firm's catching-up performance? (2) Which of the three catching-up paths has a more significant effect on the catching-up of latecomer firms? 


\section{The DeVElopment OF THE THEORY AND THE FRAMEWORK OF RESEARCH}

\section{A. The technological catching-up paths of latecomer firms}

The latecomer firms refer to firms whose technology and market are at a disadvantage [7]. Their characteristics include entering into specific industries late, lacking initial technology and market resources and possessing a relatively low market share. Latecomer firms' main strategic goal is to catch up with leading firms [8]. Many scholars focus on how these firms succeed in catching up and surpassing leading firms. The following scholars study the catching-up problems of latecomer firms from two dimensions (technology and market). Huang Yongchun et al. [9] take high-speed rail industry as an example to study the latecomer firms' choice of opportunities and strategies in the early stage of the dynamic catching-up process; Wu Xiaobo et al. [10] utilize double case longitudinal contrast analysis extending the study period from initial stage to entire catching-up process and they study the latecomer firms' impact of matching opportunity windows with innovative strategies on catching-up performance in a complete catching-up process. According to the S-curve theory, the performance of latecomer firms when introducing advanced technology is lower than that of using existing technology [11]. Therefore, the following relevant scholars focus on the technological dimension and study the static influence of different factors on technological catching-up. Liu Yang and others [12] study how organizational, geographical, and knowledgeable boundaries achieve technological catching-up; Wu Xianming et al. [13] believe that the globalization strategies have a positive effect on the technological catching-up of latecomer firms. There are also scholars studying the dynamic impact of the catching-up paths on technological catching-up. At the industrial level, Liu Jianxin and Wang Yi [14] divide the technological catching-up path of latecomer firms in the TV industry into "single path" and communication equipment industry into "multi-path", concluding that "multi-path" is better; at the enterprise level, Huang Jiangming et al. [15] study the automotive industry and divide the technological catching-up path into three patterns(leap-forward technological catching-up, local technological catching-up and high starting point technological catching-up) and explain the process of technological catching-up by analyzing Chinese auto firms. Industrial technological catching-up must rely on firms' technological catching-up. Therefore, this paper analyzes from the perspective of the firm based on the three technological catching-up paths defined by Lee and Lim [16] (path-following catching-up, path-skipping catching-up and path-creating catching-up). This paper utilizes large sample empirical analysis studying how technological catching-up paths influence catching-up performance. According to the relevant literature and analysis above, two hypotheses are made as follows.

H1: From a technical perspective, the catching-up path affects the firm's catching-up performance.

H2: Among three technological catching-up paths, the effect of the path-creating catching-up is more significant.

\section{B. Research Framework}

According to two key factors, patent quantity and market share, the firm's catching-up process is divided into three stages: backward stage, peer stage and leading stage. According to Lee [16], the catching-up paths which firms are taken are divided into three different patterns of catching-up: path-creating catching-up, path-skipping catching up and path-following catching-up. The resulting research framework is shown in Fig.1.

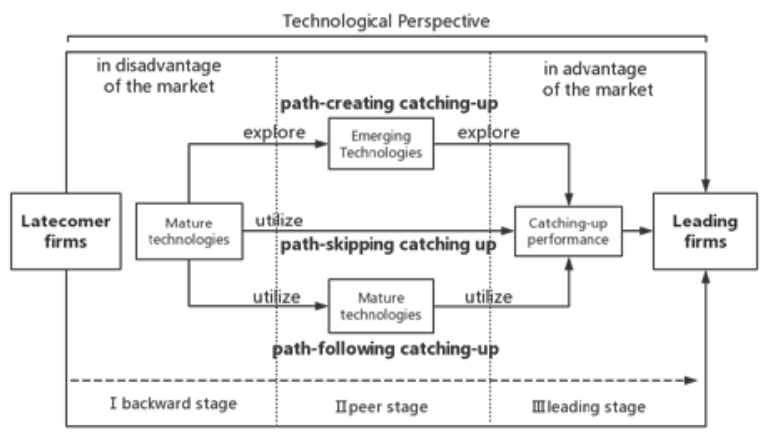

Fig.1. Theoretical Framework

This paper extends the technological catching-up process from the initial stage to the entire catching-up process including backward stage, peer stage and leadership stage. The partition of the dynamic process provides a comprehensive and systematic view in studying the catching-up paths. Chinese scholars mainly use case analysis methods studying one to three specific industries to conduct qualitative analysis. In order to obtain general rules, this paper conducts multi-case analysis and large-sample empirical analysis combining qualitative analysis with quantitative one, and breaks through the limitations of several specific industries providing a more macroscopic understanding of the effect of catching-up path choices on catching-up performance. In the perspective of technological catching-up, domestic studies mainly focus on the industrial level of the catching-up, ignoring the enterprise level. This paper constructs the framework of the technological catching-up paths at the enterprise level.

\section{EMPIRICAL ANALYSIS}

\section{A. The impact of technological catching-up paths on catching-up performance}

In the two hot industries of electronic communication industry and household appliance industry, six latecomer firms with clear development paths are selected. The catching-up process of each firm is divided into three stages: backward stage, peer stage and leadership stage according to market share, and the firms' development process is described from the technological perspective. 
TABLE I. CASE ANALYSIS

\begin{tabular}{|c|c|c|c|c|}
\hline Firms & Backward Stage & Peer Stage & Leading Stage & $\begin{array}{c}\text { Technological } \\
\text { Catching-up Path }\end{array}$ \\
\hline \multirow[b]{2}{*}{$\begin{array}{c}\text { Huawei } \\
\text { Technologies Co., } \\
\text { Ltd }\end{array}$} & 1987-1999 & $2000-2008$ & 2008 to present & \multirow[b]{2}{*}{$\begin{array}{l}\text { path-creating } \\
\text { catching-up }\end{array}$} \\
\hline & $\begin{array}{l}\text { Imitated and learned from foreign } \\
\text { advanced technology }\end{array}$ & $\begin{array}{c}\text { Used its own technological } \\
\text { advantages to develop adaptively } \\
\text { and established a joint R\&D center }\end{array}$ & $\begin{array}{c}\text { Ranking among the top } 5 \text { patent } \\
\text { applications in the world for many } \\
\text { consecutive years }\end{array}$ & \\
\hline \multirow[b]{2}{*}{$\begin{array}{l}\text { Datang Telecom } \\
\text { Technology Co., } \\
\text { Ltd. }\end{array}$} & 2017 to present & 2013-2017 & $1998-2013$ & \multirow[b]{2}{*}{$\begin{array}{l}\text { path-creating } \\
\text { catching-up }\end{array}$} \\
\hline & $\begin{array}{l}\text { The arrival of the } 5 G \text { era, behind the } \\
\text { three major operators in South Korea } \\
\text { and Huawei }\end{array}$ & $\begin{array}{c}\text { Imitated learning advanced core } \\
\text { technology and conducted } \\
\text { independent research and } \\
\text { development }\end{array}$ & $\begin{array}{c}\text { All hardware and software are } \\
\text { designed independently, breaking } \\
\text { the long-term monopoly of SIM } \\
\text { cards }\end{array}$ & \\
\hline \multirow[b]{2}{*}{ ZTE Corporation } & 1985-1995 & 1996-2002 & 2003 to present & \multirow[b]{2}{*}{$\begin{array}{l}\text { path-creating } \\
\text { catching-up }\end{array}$} \\
\hline & In-depth study of advanced technology & $\begin{array}{l}\text { Established R\&D institutions in } \\
\text { the US to introduce the latest } \\
\text { technologies in the information } \\
\text { field } \\
\end{array}$ & $\begin{array}{l}\text { Won the "2018 Global 5G } \\
\text { Infrastructure Technology } \\
\text { Leadership Award" and continue to } \\
\text { "lead" the 5G era }\end{array}$ & \\
\hline \multirow[b]{2}{*}{$\begin{array}{l}\text { Midea Group Co., } \\
\text { Ltd. }\end{array}$} & 1968-1999 & $2000-2010$ & 2011 to present & \multirow[b]{2}{*}{$\begin{array}{l}\text { path-following } \\
\text { catching-up }\end{array}$} \\
\hline & $\begin{array}{l}\text { Acquired Toshiba Wanjiale and Sanyo } \\
\text { magnetron factory, and entered the field } \\
\text { of air conditioner compressor and } \\
\text { microwave magnetron }\end{array}$ & $\begin{array}{c}\text { Acquired seven domestic } \\
\text { large-scale home appliance } \\
\text { manufacturing companies to } \\
\text { establish product groups } \\
\end{array}$ & $\begin{array}{c}\text { Acquired Toshiba, Italy's Clivet, } \\
\text { introduced core technology, and } \\
\text { changed its status to "scientific } \\
\text { enterprise" } \\
\end{array}$ & \\
\hline \multirow[b]{2}{*}{$\begin{array}{l}\text { Zhuhai Gree } \\
\text { Electric Co., Ltd }\end{array}$} & $1991-2002$ & 2002-2009 & 2009 to present & \multirow[b]{2}{*}{$\begin{array}{l}\text { path-creating } \\
\text { catching-up }\end{array}$} \\
\hline & $\begin{array}{l}\text { Purchased external technology and } \\
\text { obtained air conditioning core } \\
\text { components such as compressors }\end{array}$ & $\begin{array}{c}\text { Broke through the monopoly of } \\
\text { foreign technology and developed } \\
\text { the world's first university } \\
\text { centrifuge }\end{array}$ & $\begin{array}{l}\text { Independent research and } \\
\text { development of a number of } \\
\text { leading international technology }\end{array}$ & \\
\hline \multirow[b]{2}{*}{$\begin{array}{l}\text { Haier Group Co., } \\
\text { Ltd. }\end{array}$} & 1984-1993 & -- & 1994 to present & \multirow[b]{2}{*}{$\begin{array}{l}\text { path-skipping } \\
\text { catching-up }\end{array}$} \\
\hline & $\begin{array}{l}\text { Learned advanced technology and } \\
\text { launched Asia's first four-star } \\
\text { refrigerator }\end{array}$ & -- & $\begin{array}{c}\text { Acquire companies with mature } \\
\text { technology and continuously } \\
\text { develop and create to achieve rapid } \\
\text { growth }\end{array}$ & \\
\hline
\end{tabular}

After analyzing the catching-up process of six typical latecomer firms (see TABLE I), in the process of catching-up with the enterprise, they will choose to adopt a certain catching-up path. Therefore, for the hypothesis H1: From a technical perspective, the catching-up path affects the firm's catching-up performance and the assumption is established.

\section{B. Comparison of the Impact of Different Technology Paths on Catching-up Performance}

\section{1) Samples selection and collection}

Mainly based on the list of enterprises published in the World Brand Lab's “China's 500 Most Valuable Brand Analysis Report of 2018” [17], a total of 259 sample firms were selected, covering 10 industries including food and beverage, light industry and building materials. As of the research phase, in 2018, through the Shanghai Securities and Shenzhen Stock Exchange, the company's total assets and market share (or market share of the main business) were collected. This paper collects and summarizes the number of patents in the enterprise through the patent search engine SOOPAT website

\section{2) Modeling}

For the results of technology catching-up, the concept of "catching-up performance" was introduced. In this study, the technical path is an independent variable, and its three paths are set as dummy variables. To avoid dummy variable traps [18], for path-creating catching-up, path-skipping catching-up, 0 means not taken, 1 means taken. When the path-creating catching-up and path-skipping catching-up hopping values are both 0 , it means that the path-following catching-up is adopted.
In addition, Chen Jiagui [19] believes that enterprises as an organism will have different states at different ages. Therefore, this study adds the company's founding time as an independent variable that affects the performance of catching up.

\section{a) Structural model}

Structural model: $\eta=\Gamma \xi+\mathrm{B} \eta+\zeta, \eta$ indicates the potential dependent variable, $\xi$ indicates the potential independent variable, $\Gamma$ indicates the path coefficient of the potential independent variable affecting the dependent variable, $\mathrm{B}$ indicates the correlation coefficient matrix between potential independent variables, $\zeta$ indicates the error term.

For the mature and emerging divisions adopted in each stage, Shang Xiaohu [20] believes that there are three main aspects to measuring the innovation ability of enterprises: technology sources, paradigms, and $R \& D$, as shown in the following table. According to this standard, this study judge which technologies are mainly used by enterprises in each stage of development, and then summarizes the technological catching-up paths adopted by enterprises in the process of catching-up. [21] (See TABLE II and TABLE III below) 
TABLE II. TECHNOLOGY CLASSIFICATION

\begin{tabular}{|c|c|}
\hline Variable & Variable measurement \\
\hline \multirow[b]{2}{*}{$\begin{array}{l}\text { Source of } \\
\text { technology }\end{array}$} & Number of patents applied for in-house $R \& D$ \\
\hline & $\begin{array}{l}\text { Number of patents purchased or purchased } \\
\text { outside the enterprise }\end{array}$ \\
\hline \multirow{2}{*}{$\begin{array}{l}\text { Technical } \\
\text { paradigm }\end{array}$} & $\begin{array}{l}\text { Product production under the new technology } \\
\text { paradigm }\end{array}$ \\
\hline & $\begin{array}{c}\text { Product production under the old technology } \\
\text { paradigm }\end{array}$ \\
\hline \multirow{2}{*}{$\begin{array}{c}\text { Technology R \& } \\
\text { D } \\
\end{array}$} & R\&D of new technology investment \\
\hline & Upgrade old technology investment \\
\hline
\end{tabular}

TABLE III. TECHNOLOGICAL CATCHING-UP PATH

\begin{tabular}{|c|c|c|c|}
\hline $\begin{array}{c}\text { I backward } \\
\text { stage }\end{array}$ & $\begin{array}{c}\text { Leverage } \\
\text { proven } \\
\text { technology }\end{array}$ & $\begin{array}{c}\text { Leverage } \\
\text { proven } \\
\text { technology }\end{array}$ & $\begin{array}{c}\text { Leverage } \\
\text { proven } \\
\text { technology }\end{array}$ \\
\hline II peer stage & $\begin{array}{c}\text { Explore } \\
\text { emerging } \\
\text { technologies }\end{array}$ & -- & $\begin{array}{c}\text { Leverage } \\
\text { proven } \\
\text { technology }\end{array}$ \\
\hline $\begin{array}{c}\text { IIIleading } \\
\text { stage }\end{array}$ & $\begin{array}{c}\text { Explore } \\
\text { emerging } \\
\text { technologies }\end{array}$ & $\begin{array}{c}\text { Leverage } \\
\text { proven } \\
\text { technology }\end{array}$ & $\begin{array}{c}\text { Leverage } \\
\text { proven } \\
\text { technology }\end{array}$ \\
\hline $\begin{array}{c}\text { Catching-up } \\
\text { path }\end{array}$ & $\begin{array}{c}\text { path-creating } \\
\text { catching-up }\end{array}$ & $\begin{array}{c}\text { path-skipping } \\
\text { catching-up }\end{array}$ & $\begin{array}{c}\text { path-following } \\
\text { catching-up }\end{array}$ \\
\hline
\end{tabular}

b) Measurement model

$X=\Lambda_{\mathrm{x}} \xi+\delta, \xi$ represents a potential independent variable and $\mathrm{X}$ represents its observed variable, $\Lambda_{\mathrm{x}}$ represents the correlation coefficient matrix, $\delta$ represents the error term.

In this study, catching-up performance as a potential dependent variable, Lahiri [22] believes that the number of patents is the most intuitive observed variable to catch up with performance. In order to reduce the difference in the level of technology in different industries, the number of patents is huge, the centralization in the industry, the method of centralizing the average value between industries, and the brand value measured by the world brand laboratory, as well as the total assets of the enterprise, The market share of the company's main business [23].

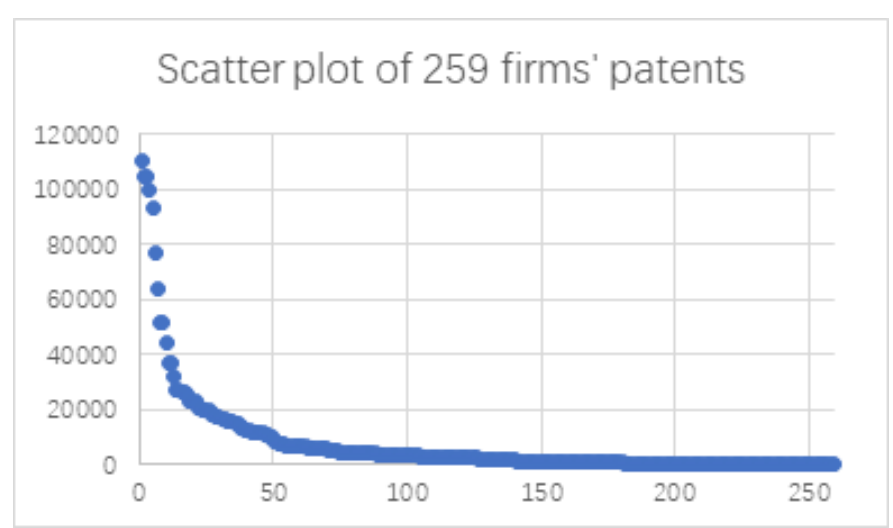

Fig.2. Number of patents

Based on the above analysis (see Fig. 2), the variables in the model are summarized as shown in the following table (see TABLE IV and Fig. 3):
TABLE IV. VARIABLE SUMMARY

\begin{tabular}{|c|c|c|c|c|}
\hline $\begin{array}{c}\text { Potential } \\
\text { variable }\end{array}$ & Number & $\begin{array}{c}\text { Measuring } \\
\text { variable }\end{array}$ & $\begin{array}{c}\text { Independent } \\
\text { variable }\end{array}$ & Number \\
\hline \multirow{2}{*}{$\begin{array}{c}\text { catching-up } \\
\text { performance } \\
(\eta 1)\end{array}$} & $\mathrm{y} 1$ & $\begin{array}{c}\text { Brand } \\
\text { Value }\end{array}$ & $\begin{array}{c}\text { path-creating } \\
\text { catching-up }\end{array}$ & $\mathrm{x} 1$ \\
\cline { 2 - 5 } & $\mathrm{y} 2$ & $\begin{array}{c}\text { Logarithm } \\
\text { of total } \\
\text { assets of } \\
\text { the } \\
\text { enterprise }\end{array}$ & $\begin{array}{c}\text { path-skipping } \\
\text { catching-up }\end{array}$ & $\mathrm{x} 2$ \\
\cline { 2 - 5 } & $\mathrm{y} 3$ & $\begin{array}{c}\text { Market } \\
\text { share of the } \\
\text { company's } \\
\text { main } \\
\text { business }\end{array}$ & $\begin{array}{c}\text { Founding } \\
\text { time }\end{array}$ & $\mathrm{x} 3$ \\
\cline { 2 - 6 } & $\mathrm{y} 4$ & $\begin{array}{c}\text { Number of } \\
\text { patents }\end{array}$ & -- & -- \\
\hline
\end{tabular}

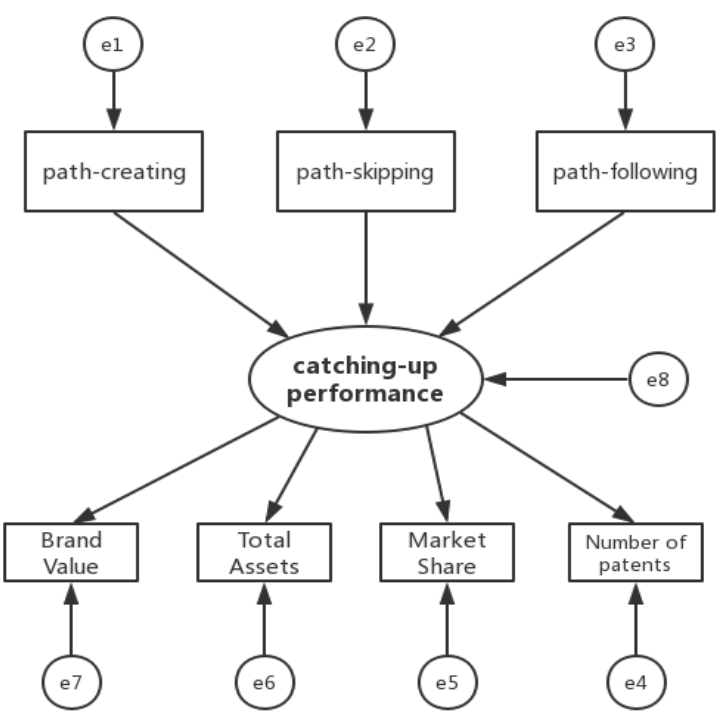

Fig.3. Mixed Path Diagram

\section{Result analysis}

According to the technological catching-up path, the latecomer firms' classification is as the following Fig. 4

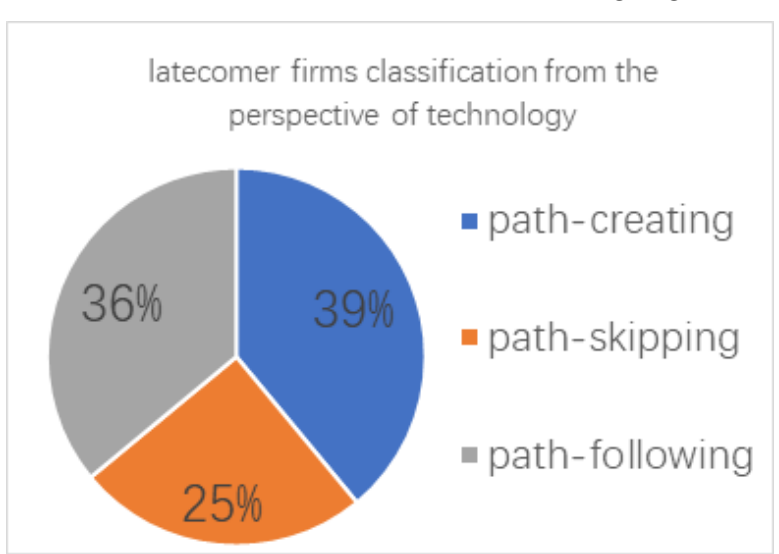

Fig.4. Firms Classification

As can be seen from the above figure, among the 259 samples, the proportion of companies that choose the 
path-creating catching-up is up to 39\%, and the number of companies that choose the path-skipping catching-up is $25 \%$.

1) Relationship between catching-up paths and the number of patents

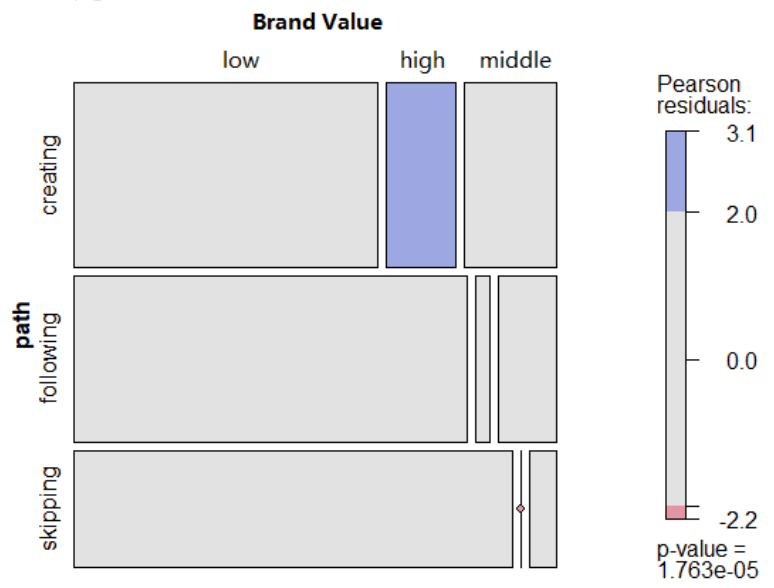

Fig.5. Mosaic about Catching-up Paths and Brand Value

In Fig. 5, the column length and width and the thickness represent the proportion in the classification. The illustrated color represents the residual of the actual value and the predicted value, blue represents that actual value is better than the predicted value, and red is the opposite.

As can be seen from the above figure, among the low brand value $(<1200)$, medium (1200-2500), high $(>2500)$ classification, when the brand value is high, path-creating accounts for the largest proportion of technological paths and path-skipping accounts for the smallest. The three distributions of brand values under the three technological paths are roughly the same, with low value accounting for the highest proportion and high value accounting for the lowest proportion. The number of companies with high brand value in the path-creating is more than predicted, and it indicates that the enterprises of high brand value prefer to take path-creating.

2) Relationship between catching-up paths and the number of patents
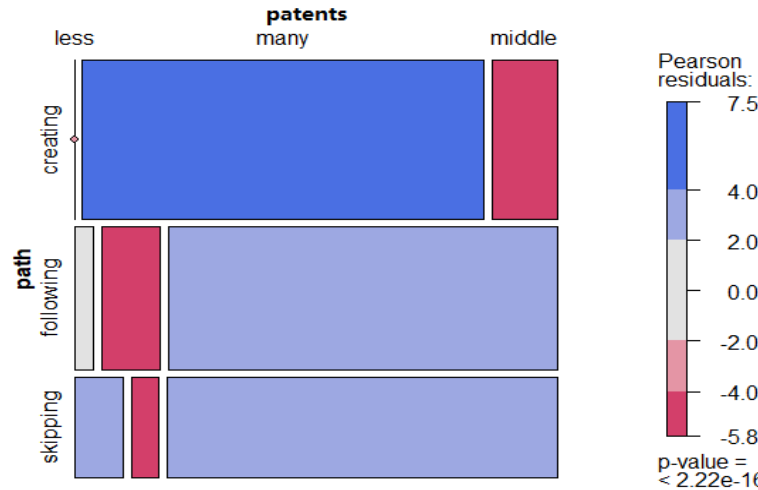

Fig.6. Mosaic about Catching-up Paths and the Number of Patents
As can be seen from the above Fig. 6, the number of patents is classified into three groups, as less $(<-0.8)$, middle $(-0.8-1)$, and many $(>1)$. When the number of patents is many, path-creating takes the largest proportion in the technological catching-up paths, path-skipping takes the smallest proportion. The three distributions of the number of patents under the three different technological catching-up paths are quite different individually. Under the path-creating, enterprises with a large number of patents account for the largest proportion, and those with a small number of patents account for the least proportion. Under the path-following, accounting for the largest proportion of enterprises are those with the medium number of patents, the smallest proportion of enterprises are those with a small number of patents. Under the path-skipping, the largest proportion of enterprises is also the medium numbers of patents, the smallest proportion of enterprises are those with a large number of patents.

The number of companies with a large number of patents in the path-creating is more than predicted, and the number of enterprises with medium patents among the three technological paths is less than predicted. It indicates that among enterprises with a large number of patents, the probability of path-creating is the greatest.

\section{3) Measurement model test}

$$
\begin{aligned}
\text { composite reliability } & =\frac{\left(\sum \lambda\right)^{2}}{\left[\left(\sum \lambda\right)^{2}+\sum \theta\right]} \\
& =\frac{8.066}{10.146}=0.795>0.05
\end{aligned}
$$

Indicator variables can effectively reflect latent variables, and potential variables have certain validity and reliability.

\section{4) Path coefficient}

TABLE V. STANDARD PATH REGRESSION COEFFICIENT TABLE

\begin{tabular}{|c|c|c|c|c|c|c|}
\hline & & Estimate & S.E. & C.R. & P \\
\hline $\begin{array}{c}\text { Catching-up } \\
\text { performance }\end{array}$ & $<--$ & $\begin{array}{c}\text { path-creating } \\
\text { catching-up }\end{array}$ & .667 & .187 & 7.942 & $* * *$ \\
\hline $\begin{array}{c}\text { Catching-up } \\
\text { performance }\end{array}$ & $<--$ & $\begin{array}{c}\text { Founding } \\
\text { time }\end{array}$ & -.027 & .001 & -.484 & .628 \\
\hline $\begin{array}{c}\text { Catching-up } \\
\text { performance }\end{array}$ & $<--$ & $\begin{array}{c}\text { path-skipping } \\
\text { catching-up }\end{array}$ & -.148 & .129 & -2.250 & .024 \\
\hline $\begin{array}{c}\text { Number of } \\
\text { patents }\end{array}$ & $<--$ & $\begin{array}{c}\text { catching-up } \\
\text { performance }\end{array}$ & .854 & -- & -- & -- \\
\hline \begin{tabular}{c} 
Total assets \\
\hdashline Brand \\
Value
\end{tabular} & $<---$ & $\begin{array}{c}\text { catching-up } \\
\text { performance }\end{array}$ & .579 & .171 & 8.047 & $* * *$ \\
\hline $\begin{array}{c}\text { Market } \\
\text { share }\end{array}$ & $<---$ & $\begin{array}{c}\text { catching-up } \\
\text { performance }\end{array}$ & .661 & 79.017 & 8.730 & $* * *$ \\
\hline
\end{tabular}

As can be seen from the above TABLE V, the founding time and catching-up performance path coefficients are not significant, and the rest are significant at 0.05 significant levels. The path coefficient does not significantly indicate that the founding time does not affect the catching-up performance. There are hundreds of old stores in the samples, and there are also rising stars. The difference of time is large but they all have developed into leaders in their industry. The path coefficient significantly indicates that there is a strong 
correlation between the technological catching-up path and the catching-up performance, and the mediating effect of catching-up performance is better.

The path coefficient of the path-creating and catching-up performance is 0.667, which indicates that, on average, the pat-creating changes by one unit, and the impact catching performance increases by 0.667 units compared with the unit of the path-following. By the same token, each change in the path-skipping compared to each change in the path-following that changes the catching-up performance were reduced by 0.148 units.

Therefore, the rate of change affecting catching-up performance under the path-creating is greater than the path-following, both of which are larger than the path-skipping catching-up.

H2: Among three technological catching-up paths, the effect of the path-creating catching-up is more significant, and the assumption is established.

\section{5) Total effects}

TABLE VI. TOTAL EFFECT

\begin{tabular}{|c|c|c|}
\hline & $\begin{array}{c}\text { Path-creating } \\
\text { catching-up }\end{array}$ & $\begin{array}{c}\text { Path-skipping } \\
\text { catching-up }\end{array}$ \\
\hline Brand Value & .441 & -.098 \\
\hline Market share & .502 & -.111 \\
\hline Total assets & .386 & -.086 \\
\hline $\begin{array}{c}\text { Number of } \\
\text { patents }\end{array}$ & .570 & -.126 \\
\hline \multicolumn{2}{|c|}{ Chi-squre=101.647 DF=12 P=0.000 } \\
\hline
\end{tabular}

It can be seen from the above TABLE VI that the unit change in the path-creating that affects brand value, market share, total assets, and patent quantity is all greater than the path-following. The difference of the effect of the number of patents is the largest, and the effect of total assets is the smallest. Enterprises that use the path-creating often have a strong independent innovation capability, and there will be a big gap between the number of patents and the companies in path-following.

Similarly, the path-skipping affects the unit change of the measured variable, which is slightly less than the compliance path. The effect of the number of patents and the path-following are large, and the effect on the total assets is the smallest. Enterprises in path-skipping tend to be shorter than others, skipping some stages of development, and are lower in number of patents than those in path-following.

\section{Model evaluation}

In this study, the absolute fit index, the value-added fit index, and the simple fit index [24] are selected, and the corresponding indicators are selected for evaluation, as shown in the following table:

TABLE VII. TEST STATISTICS

\begin{tabular}{|l|l|}
\hline Test statistics & Default model \\
\hline GFI & $0.904>0.90$ \\
\hline RMSEA & 0.164 (suitable) \\
\hline NFI & 0.856 \\
\hline
\end{tabular}

\begin{tabular}{|l|l|}
\hline \multicolumn{2}{|c|}{ Cont. to TABLE VII. } \\
\hline CFI & $0.969>0.90$ \\
\hline PGFI & $0.584>0.50$ \\
\hline AIC & $\begin{array}{l}133.647<156(\text { Saturated model) } \\
<242.943(\text { Independence model) }\end{array}$ \\
\hline
\end{tabular}

Except for the above statistics (see TABLE VII), except NFI ( $>0.90$ ), the other statistics have reached the requirements. The model has a good fitting effect and analytical value, and the results are credible.

\section{CONCLUSIONS AND RECOMMENDATIONS}

\section{A. According to regression analysis, the relationship between} the founding time of the firm and the catching-up performance is not statistically significant

On the one hand, the long-term establishment of the enterprise enables the enterprise to have a mature technical system and rich production experience. On the other hand, it may make the enterprise technology system rigid, and the emerging technology and technological innovation tend to be conservative. The short-term establishment of the enterprises, for example, Huawei, which was established in 1987, has taken the lead in the global 5G market within only 32 years, and it is inclined to introduce innovations in the face of emerging technologies. Under the process of catching-up, centuries-old stores and emerging enterprises have their own advantages and disadvantages. The age of the firm will not affect the firm's own catching-up performance. The latecomer firms need to keep a balance between pursuing technological innovation and establishing mature technological system.

\section{B. Technological catching-up paths determine the catching-up performance}

Although different industries have large gaps in the performance of the technological path, such as the electronic communication enterprise ZTE and the home appliance manufacturing enterprise Gree has a huge gap in the investment of innovative technology. However, according to the previous analysis, the creation path is adopted by both of them. After analyzing 259 enterprises, path-creating catching-up is the most statistically significant path among the three paths with path-following catching-up ranking the second and path-skipping catching-up ranking the third. In the early stage of the latecomer firm, it was in a situation of less market share and lack of core technology. In the face of mature technology that the leader has already created, it can be introduced to quickly realize the accumulation of original capital. In the peer stage, the impacts of the development of both core technologies to enhance self-innovation ability and continually learn from the predecessor technology need to be considered. Although a firm can achieve catching-up performance growth through any of the two, according to the analysis, the former can independently master the core technology of the industry, the efficiency of scale expansion is better than the latter one and ultimate outcome of becoming a leader to catch up with performance is also better. Latecomer firms should pay attention to the issue of independent innovation, and mastering core technology to achieve catching-up. 


\section{The three catching-up paths have a weak impact on the total assets and brand value of the enterprises, but a strong impact on market share and patent number}

In order to increase total assets and improve brand value, all three paths can be selected. However, this study believes that if the latecomer firms want to establish a solid leadership position, they still need to strive for a larger market share. Market share can sensitively reflect the operation of the company and guide the future development of the company. The latecomer firms should not only focus on the growth of the company's total assets, but also focus on market share and improve the competitiveness of core technology for long-term development.

\section{LIMITATION}

This study still has some shortcomings and areas to be explored. The follow-up research can be carried out from the following two aspects: (1) Based on technological innovation, a more in-depth and comprehensive dynamic synergy analysis which combines both business models and government policies should be taken into consideration; (2) More systematic and theoretical adjustments to the key factors which affect the performance of latecomer firms.

\section{REFERENCES}

[1] ZANG Shuwei, PAN Xuan, SUN Qianmin, "Latecomer Firms' Catching-up Strategy under the Dynamic Environment--Based on Business Model Innovation,” Research on Economics and Management, vol. 39, pp. 123-132, August 2018. (In Chinese)

[2] WU Dong, WU Xiaobo, "Technological Catching-up: China's Context and Its Implications,” Studies in Dialectics of Nature, vol. 29, pp. 45-50, November 2013. (In Chinese)

[3] LIN Runhui, ZHOU Changbao, LI Kanghong, XIE Zongxiao, "Innovation Ability Building of the Latecomer Firms in the Process of Technological Catching-up--A Case Study Based on China XD Group Co., LTD,” R\&D Management, vol. 28, pp. 40-51, February 2016. (In Chinese)

[4] LIU, X, "China's Catch-up and Innovation Model in IT Industry," International Journal of Technology Management, vol 51, pp. 194-216, February 2010. (In Chinese)

[5] CHEN Zu, SHAO Mingjie, "Later Innovation Model and Path Based on the Dimension of Independent R\&D and Introducing and Rebuilding," Statistics and Decision-making, vol. 18, pp. 53-56, 2018. (In Chinese)

[6] WU Xiaobo, FU Yanan, WU Dong, LEI Linan, "How Do Latecomers Transform from Catch-up to Beyond Catch-up? A Longitudinal Comparative Analysis of Two Cases Based on Window of Opportunity Perspective," Management World, vol. 2, pp. 151-166, February 2019. (In Chinese)

[7] Hobday, M., "East Asian Latecomer Firms: Learning the Technology of Electronics,” World Development, vol. 23, pp. 1171-1193, July 1995.
[8] HU, M. C., J. A. Mathews, "National Innovative Capacity in East Asia," Research Policy, vol. 34, pp. 1322-1349, September 2005.

[9] HUANG Yongchun, Wang Zuli, Xiao Yapeng, "The technology Catching-up Opportunity and Performance of Emerging Giants' Enterprises-Based on the Theoretical and Empirical Analysis of Strategic Emerging Industry,” Science Research Management, vol. 38, pp. 81-90, July 2017. (In Chinese)

[10] WU Xiaobo, "How Do Latecomers Transform from Catch-up to Beyond Catch-up? A Longitudinal Comparative Analysis of Two Cases Based on Window of Opportunity Perspective," Management World, vol. 35, pp. 151-167, February 2019. (In Chinese)

[11] Foster, R. N., "Innovation: The Attacker's Advantage," Macmillan, London,1986. (In Chinese)

[12] LIU Yang, WEI Jiang and JIANG Shisong, "How do Latecomer Firms Catch up in Innovation? A Study from the Perspective of the Boundary Expanding in R\&D,” Management World, vol. 3, pp. 96-188, 2013. (In Chinese)

[13] WU Xianming, HU Bowen, "Internationalization of Latecomer Firms and Technological Catch-up Performance: An Empirical Analysis based on 2003-2013 Interprovincial Panel Data,” Commercial Research, vol. 1, pp. 97-104, 2018. (In Chinese)

[14] LIU Jianxin, WANG Yi, "Study on Relationship between Industrial Technological Catch-up Mode and Performance in Backward Countries," Science Research Management, vol. 34, pp. 68-74, August 2013. (In Chinese)

[15] HUANG Jiangming, ZHAO Ning, "Logic of Resources and Decisions: A Research on the evolution of Technology Catch up in BAIC Group," Management World, vol. 9, pp.120-130, 2014. (In Chinese)

[16] Lee K, Lim C., "Technological Regimes, Catching-up and Leapfrogging: Findings from Korea Industries,” Research Policy, vol.3, pp.459-483, 2001.

[17] World Brand Lab, 2018 China's 500 Most Valuable Brand Analysis Report, Beijing: World Brand Lab, 2018.

[18] James H. Stock., Introduction to Econometrics Third Edition, Third Edition, Gezhi Publishing House, April 2012.

[19] CHEN Jiagui, "Discussion on Enterprise Life Cycle and Enterprise Evolution,” China Industrial Economics, vol. 11, pp. 5-13, 1995. (In Chinese)

[20] SHANG Xiaohu, "Research on the Technology Innovation Patterns of China's Manufacturing Industry,” Shanghai Academy of Social Sciences, 2013. (In Chinese)

[21] WEI Jiang, XU Ruiqing, "The Concept, Structure, Measurement and Evaluation of Enterprise Innovation Ability,” Scientific Management Research, vol. 13, pp. 50-55, October 1995. (In Chinese)

[22] Lahiri N., "Geographic Distribution of R\&D Activity: How Does It Affect Innovation Quality?” Academy of Management Journal, vol. 53, pp. 1194-1209, May 2010.

[23] Hofmann D.A., Gavin M.B., "Centering Decisions in Hierarchical Linear Models: Implications for Research in Organizations,” Journal of Management, vol. 24, pp. 623-641, May 1998.

[24] CHEN Yushu, HUANG Caiwei, HUANG Fangming, The basic principle of the structural equation model, 2006. Kaohsiung: Liwen, 2006. (In Chinese) 